\title{
Synthesizing Nile crocodile Crocodylus niloticus attack data and historical context to inform mitigation efforts in South Africa and eSwatini (Swaziland)
}

\author{
Simon Pooley, Hannes Botha, Xander Combrink and George Powell
}

\begin{abstract}
Conflicts with wildlife are a major challenge for conservation across Africa, and Nile crocodiles Crocodylus niloticus are allegedly responsible for more attacks on people than any other species; however, there is a lack of data regarding such attacks. We analysed reported attacks on people by Nile crocodiles in South Africa and eSwatini (Swaziland) during 1949-2016, identifying spatial and temporal patterns in attack incidence, as well as victim demographics. Through a literature review and archival searches we identified records of 214 attacks. Most attacks occurred in natural water bodies, with attacks in dams increasing since 2000. Most victims were attacked while swimming or bathing, others while fishing, doing domestic chores, and crossing waterways. There was a significant relationship between gender and activity when attacked. Children ( $<16$ years old) accounted for $51 \%$ of all attacks, with a higher fatality rate compared to adults. Most victims were male $(65 \%)$, with teenage boys being the largest individual category. We make recommendations for conservation policy and management to mitigate attacks by Nile crocodiles.
\end{abstract}

Keywords Conservation management, crocodile attacks, human-wildlife conflict, eSwatini (Swaziland), Nile crocodile, South Africa

\section{Introduction}

mong the wild animals that attack people and their livestock across Africa, crocodiles (the Nile crocodile

\footnotetext{
SimON PoOLEY* (Corresponding author, (D) orcid.org/0000-0002-0260-6159) Department of Geography, Birkbeck University of London, 32 Tavistock Square, London, WC1H 9EZ, UK. E-mail s.pooley@bbk.ac.uk

Hannes Botha $\dagger$ Scientific Services, Mpumalanga Tourism and Parks Agency, Nelspruit, South Africa

Xander Combrink Department of Conservation Science, Tshwane University of Technology, Pretoria, South Africa

George Powell Department of Life Sciences, Imperial College London, London, UK

${ }^{*}$ Also at: School of Life Sciences, University of KwaZulu-Natal, Pietermaritzburg, South Africa, and WildCRU, University of Oxford, Tubney, UK

$\dagger$ Also at: Department of Biodiversity, University of Limpopo, Sovenga, South Africa

Received 13 June 2018. Revision requested 26 July 2018.

Accepted 8 August 2018. First published online 11 July 2019.
}

Crocodylus niloticus and the West African crocodile Crocodylus suchus) are widely distributed and are claimed to be responsible for most attacks on people (e.g. Lamarque et al., 2009; Dunham et al., 2010). Male Nile crocodiles may exceed $4 \mathrm{~m}$ in length, and grow up to $5 \mathrm{~m}$ in exceptional cases, taking large prey such as wildebeest Connochaetes spp. and buffalo Syncerus caffer. They are adaptable to local environmental conditions and occur in a wide range of natural and human-made aquatic habitats, such as canals and dams, where they increasingly come into contact with people and their livestock.

Increasing human populations and utilization of rivers, lakes, wetlands and dams (from small farm dams to large irrigation dams), as well as gillnetting (for fish), are resulting in an increasing number of human-crocodile interactions and a perception that adverse encounters between people and crocodiles are increasing (Aust et al., 2009; Lamarque et al., 2009; Fergusson, 2010; Wallace et al., 2011; Zakayo, 2014). The online database CrocBITE (2018) contains records of attacks in 29 African countries, and attacks are known to have occurred in one additional country (Kpéra et al., 2014).

Research articles on crocodile attacks are revealing informative spatial and temporal patterns in attacks, and provide useful information about the demographics of attack victims (recent examples include Brien et al., 2017; Shaney et al., 2017; Vyas \& Stevenson, 2017; Das \& Jana, 2018), but data for Nile crocodiles are inadequate. Published data of varying quality and quantity (most not peer reviewed) exist for 12 of the 30 African countries where attacks are known to occur (Pooley, 2018). More data, as well as reviews of mitigation efforts, are required urgently (Fergusson, 2010; Pooley, 2015a).

Here we present an analysis of 67 years of data on crocodile attacks on people in South Africa and the Kingdom of Swaziland (now eSwatini) during 1949-2016. We use the resulting generalizations to investigate some of the patterns and challenges identified in specific locations, in the context of the history and management of crocodile attacks in the study region. Drawing on attack data and historical evidence, we suggest ways forward for conservation policy and management of human-crocodile relations in the study region.

\section{Study area}

This study focuses on north-eastern South Africa, including the warmer, low-lying (lowveld) region of the interior 


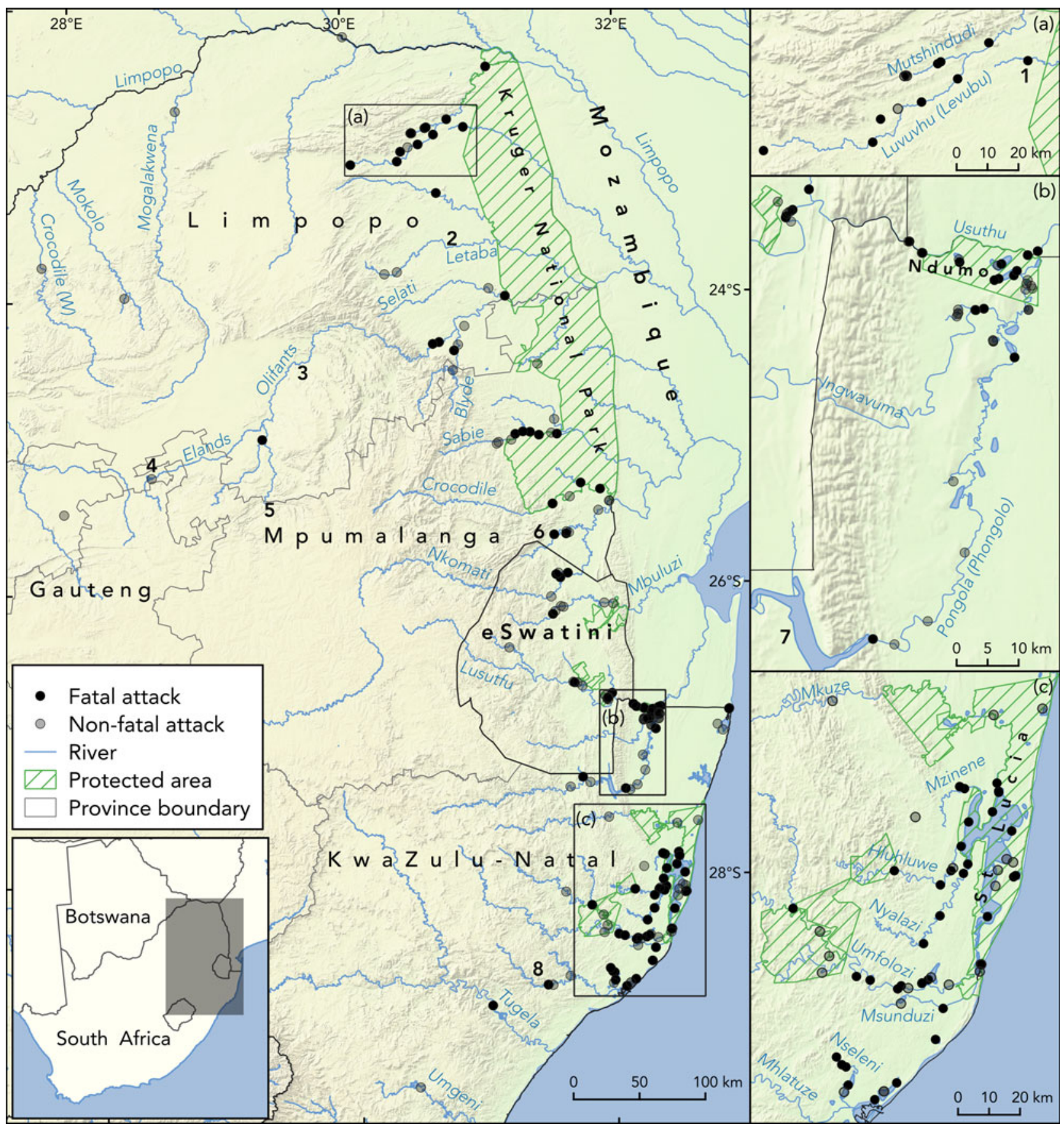

FIG. 1 North-eastern South Africa and eSwatini (Swaziland), with the provinces of South Africa, key protected areas, rivers in which crocodile attacks have occurred, and the locations of fatal and non-fatal attacks. Dams shown on the map are: (1) Makuleke Dam, (2) Middle Letaba Dam, (3) Flag Boshielo Dam, (4) Rust de Winter Dam, (5) Loskop Dam, (6) Driekoppies Dam, (7) Pongolapoort Dam, and (8) Goedertrouw Dam.

confined mainly to Limpopo and Mpumalanga Provinces, and northern KwaZulu-Natal Province (KZN), and the lower-lying warmer areas of eSwatini (Fig. 1). Nile crocodile distribution in the region is limited to the warmer, summer rainfall regions of these countries, with the hot and wet season (minimum temperatures $>15{ }^{\circ} \mathrm{C}$ ) during OctoberMarch (November-March in the interior of South Africa).
Most of the rivers flow eastwards, from the central plateau and eastern escarpment to the Indian Ocean.

During c. 1949-1992 South Africa's black African majority was persecuted under the system of Apartheid, with resettlement in remote rural homelands with poor land and few jobs, and men working in cities as migrant labourers. This system kept two-thirds of the population rural (some 
TABLE 1 Country statistics for South Africa and eSwatini, 2018 (UNDP, 2018).

\begin{tabular}{|c|c|c|c|c|c|}
\hline & $\begin{array}{l}\text { UNDP Human Development } \\
\text { Index (country rank, of 188) }\end{array}$ & Population (millions) & Median age (years) & $\%$ unemployed & $\%$ urban \\
\hline South Africa & $0.699(113)$ & 56.7 & 26.1 & 27.7 & 65.8 \\
\hline eSwatini & $0.588(144)$ & 1.4 & 20.4 & 26.4 & 23.6 \\
\hline
\end{tabular}

of them more likely to encounter crocodiles) until the early 1980s, when Apartheid began to fail. Apartheid influx laws were defied, and urbanization accelerated, especially after an African National Congress-led government came to power in 1994 (Turok, 2012). Employment in the agricultural sector is now low (5.6\%) and declining, with unemployment much higher in rural areas (Turok, 2012; UNDP, 2018).

Census data (decadal, from 1951) are of limited use for investigating relationships between human population densities and crocodile attacks in particular locales. Data from the Apartheid era are considered to be highly questionable (Christopher, 2011), the borders of magisterial districts varied across the study period (Giraut \& Vacchiani-Marcuzoo, 2009), and estimates of human population density exist only at a coarse scale (magisterial districts; Table 1 ).

eSwatini is a small, stable absolute monarchy with a largely rural population. The population increased sixfold during the study period. eSwatini is categorized as a lowermiddle income country, and the majority of Swazis are poor, with an estimated $70 \%$ of the population employed in subsistence farming (CIA, 2017; UNDP, 2018). Many Swazis depend on rivers for water, for drinking, cooking and washing.

\section{Crocodile populations and threats}

There are naturally occurring wild Nile crocodiles as far south as the Zinkwazi River in South Africa but the major viable populations are restricted to three disjunct protected areas: the eight large seasonal and perennial rivers traversing Kruger National Park in Limpopo and Mpumalanga provinces; and in KwaZulu-Natal Province, in Ndumo Game Reserve and the Lake St Lucia estuarine system (Ferreira \& Pienaar, 2011; Combrink et al., 2013; Calverley \& Downs, 2014a).

Crocodile abundance in Kruger National Park peaked in the early 1990 and then declined during 1993-2000, but has since increased to an estimated 4,300 individuals $>1 \mathrm{~m}$ in length. This is despite die-offs since 2008 , caused by the nutritional disease pansteatitis (Ferreira \& Pienaar, 2011). In Limpopo and Mpumalanga provinces, outside the Park just over 600 individuals were counted in the 1980s, most $<_{3} \mathrm{~m}$ in length, with breeding populations in the Olifants, Limpopo, Luvuvhu, Komati and Blyde rivers (Jacobsen, 1984). At the time of writing, only the $12.8 \mathrm{~km}^{2}$ Flag Boshielo Dam on the Olifants River retained a viable crocodile population outside Kruger National Park in Mpumalanga Province (Botha, 2005). This population declined by $27 \%$ following the raising of the dam wall by $5 \mathrm{~m}$ in 2006 (Ashton, 2010).

In northern KwaZulu-Natal Province, populations declined after World War II as a result of hunting and snaring, as well as habitat destruction and water shortages caused by the expanding agriculture and forestry sectors. Tony (A.C.) Pooley started a crocodile restocking programme in 1966, which in combination with legal protection (effective from 1969 ) resulted in a significant recovery by the 1990s (Pooley, 1982; Calverley \& Downs, 2014a; Harvey \& Marais, 2014).

However, the Ndumo Game Reserve population decreased by $38 \%$ during $1993-2009$, possibly because of an increase in illegal killings and disturbance facilitated by the removal of the eastern boundary fence in May 2008 (Calverley \& Downs, 2014 b); in 2009 the population comprised 516 crocodiles.

The first aerial survey of Lake St Lucia (1972) recorded 356 crocodiles $>1 \mathrm{~m}$ (Pooley, 1982). The lake was restocked with juvenile crocodiles during 1967-1976 (Pooley, 1980), and 975 individuals were counted in 1993. The population remained stable until 2008 but has since declined, possibly as a result of prolonged drought (Combrink, 2014).

With the exception of the $132 \mathrm{~km}^{2}$ Pongolapoort Dam in KwaZulu-Natal (Champion \& Downs, 2017), declines have been reported for all major crocodile populations in South Africa. As a result, Nile crocodiles are categorized as Vulnerable in the country (Harvey \& Marais, 2014).

In eSwatini, extensive habitat has been converted for agriculture, and illegal hunting remained rife into the 1980s. In 1992 King Mswati III ordered a new draft of the Game Act (1953, as amended), passed in 1993, which introduced the first legal protection for crocodiles outside protected areas (Big Game Parks, 2017). No crocodile population data are available for eSwatini, but the species is considered to be Vulnerable there (Harvey \& Marais, 2014).

\section{Conservation management}

Ezemvelo KZN Wildlife is the responsible authority in KwaZulu-Natal, South Africa. They remove rather than kill crocodiles whenever possible, and do not erect or maintain protective structures, or pay compensation for attacks outside protected areas. The Mpumalanga Tourism and Parks Agency and Limpopo Province's Department of Economic Development, Environment and Tourism deal 
with attacks in the interior. Crocodiles are protected under provincial conservation legislation.

In Mpumalanga problem crocodiles are trapped and released in either the $24 \mathrm{~km}^{2}$ Loskop Dam or Flag Boshielo Dam (H. Botha, pers. obs.), or sold to commercial farms. The Limpopo authorities have issued tenders licensing trophy hunters to control damage-causing crocodiles but few have been destroyed in this way. Fences have been built at some dams (Anthony et al., 2010).

In eSwatini, Big Game Parks is mandated by the office of the King to manage wildlife in the royal parks and outside protected areas. Their policy is to capture and remove confirmed problem crocodiles. No protective structures are built, and compensation is not paid (Mick Reilly, Big Game Parks, pers. comm., 2014).

\section{Methods}

Information on attacks by Nile crocodiles was obtained from the personal archives of Tony (A.C.) Pooley and Ian Player, the St Lucia Crocodile Centre, and the Times of Swaziland archive in Mbabane, eSwatini. We searched newspaper reports (print and online), journals and popular magazines, using the search term 'crocodile' paired with 'attack', 'bite' or 'victim', in English and Afrikaans.

Only details of attacks by wild crocodiles that resulted in injury or death were included. Alleged attacks that were not witnessed or that lacked forensic proof were excluded. Fatal attacks include attacks from which victims died later as a result of injuries sustained. Demographic categories for age were child ( $<16$ years) and adult $(\geq 16$ years; sometimes exact age data were missing but victims were described as children or adults), and 5-year age categories were used for cases for which exact age data were available.

We excluded crocodile attacks prior to 1949 because of a paucity of reliable data. It is likely that during the study period some attacks involving minor injuries went unreported. In remote regions, particularly areas to which people were relocated by Apartheid authorities, some serious attacks may have gone unreported.

Historical rainfall and temperature data were obtained from NOAA (2017) and NOAA Central Library (2013). All mean values of rainfall and temperature are for 30 -year periods.

We tested for temporal trends by constructing Poisson generalized linear models of attack frequency as a function of year. Quasi-Poisson generalized linear models were constructed when the data were overdispersed. We tested for differences between victim demographic categories using $\chi^{2}$ tests.

\section{Results}

Literature searches returned 132 print newspaper stories and six magazine features for South Africa, and 15 print newspaper stories of attacks in eSwatini. Sixteen online stories were retrieved through Google searches and searches of digital archives of five South African newspapers (in English and Afrikaans), and nine stories from the digital archives of two Swazi newspapers. Tony Pooley's archive included personal records of 73 attacks in the study region, and Ian Player's archive included 15 newspaper reports of attacks.

The dataset comprises 214 crocodile attacks for the period 1949-2016: 185 attacks in South Africa and 29 in eSwatini. In South Africa, attacks have been recorded in 13 district municipalities but only five districts have more than five attacks recorded. Fig. 1 shows the spatial distribution of attacks, highlighting the provinces and water bodies with the highest numbers of recorded attacks.

Attack locations The majority of crocodile attacks occurred in natural water bodies (Table 2), with $69 \%$ of attacks in rivers or streams $(n=148), 15 \%$ in lakes or pans $(n=33), 3 \%$ in the St Lucia estuary $(n=7)$ and $1 \%$ in wetlands $(n=2)$. Attacks have also been recorded in man-made water bodies, with $8 \%$ in dams of various sizes $(n=18)$ and $2 \%$ in canals or drains $(n=5)$. The exact location of one attack $\left(<_{1} \%\right)$ is unknown.

Annual trends A Poisson generalized linear model indicates no significant trend in annual attack frequency across South Africa (eSwatini attack data for before 2000 are patchy) during 1949-2016 (estimate $=0.002, z=0.529$, $\mathrm{P}=0.597$ ). However, the records indicate some temporal trends in particular districts and locality types. For example, there has been a significant decrease in the number of attacks reported in the Umkhanyakude district since 1949 (estimate $=-0.026, \mathrm{SE}=0.007, t=-3.996, \mathrm{P}<0.001$ ), with only one attack recorded since 2010. In comparison, there has been a significant increase in the number of attacks reported in Limpopo Province's Mopani district (estimate $=$ $0.072, \mathrm{SE}=0.024, z=2.997, \mathrm{P}=0.003$ ) and Vhembe district (estimate $=0.047, \mathrm{SE}=0.017, z=2.756, \mathrm{P}=0.006$ ). During 2006-2016 eight attacks were recorded in Mopani district and six in Vhembe district, accounting for $32 \%$ of all attacks recorded during this period $(n=44)$. Fig. 2 shows the number of attacks recorded by 5 -year period for the five municipal districts in South Africa with the highest number of attacks. There have been temporal trends in attack frequency for different water body types. For example, there was a significant increase in the frequency of attacks reported in dams between 1949 and 2016 (estimate $=0.065$, $\mathrm{SE}=0.018, z=3.703, \mathrm{P}<0.001$ ), with $64 \%$ of all reported attacks in dams occurring post 2000, and a record high of six attacks recorded in dams in 2014.

Seasonality of attacks There seems to be a strong relationship between crocodile attacks and season (Fig. 3a,b), 
TABLE 2 Major locations for attacks by Nile crocodiles Crocodylus niloticus in South Africa and eSwatini (1949-2016).

\begin{tabular}{|c|c|c|c|}
\hline River or other water body & $\begin{array}{l}\text { Province (South Africa) } \\
\text { or country (eSwatini) }\end{array}$ & $\begin{array}{l}\text { Years in which attacks were } \\
\text { recorded during 1949-1999 }\end{array}$ & $\begin{array}{l}\text { Years in which attacks were } \\
\text { recorded during 2000-2016 }\end{array}$ \\
\hline $\begin{array}{l}\text { Pongola River \& floodplain pans } \\
\quad \text { (including Ndumo Game Reserve) }\end{array}$ & KwaZulu-Natal & $\begin{array}{l}1952,1954,1960,1963, \\
1964-1967,1969-1972, \\
1986,1988,1990\end{array}$ & 2000 \\
\hline Lake St Lucia estuarine system & KwaZulu-Natal & $\begin{array}{l}1952,1956,1957,1960, \\
1961,1969,1972,1990,1995\end{array}$ & $2000,2002,2005,2012$ \\
\hline Umfolozi River (\& canals) & KwaZulu-Natal & $\begin{array}{l}1956,1960,1962,1969, \\
1970,1984,1991,1996,1999\end{array}$ & 2005,2010 \\
\hline $\begin{array}{l}\text { Usutu River \& linked pans } \\
\quad \text { (including Ndumo Game Reserve) }\end{array}$ & KwaZulu-Natal, eSwatini & $\begin{array}{l}1958,1959,1961,1965 \\
1967,1968,1987\end{array}$ & $\begin{array}{l}\text { 2000, 2001, 2003, 2007, } \\
\text { 2008, 2009, 2011, 2013, } 2015 \\
\text { (all eSwatini) }\end{array}$ \\
\hline Komati River & Mpumalanga, eSwatini & $\begin{array}{l}1957,1984,1986,1987 \\
1989,1992\end{array}$ & 2007,2016 \\
\hline Mbuluzi River & eSwatini & 1951,1958 & $2002,2004,2007,2011,2014$ \\
\hline Luvuvhu River & Limpopo & $1958,1972,1980$ & $2002,2006,2016$ \\
\hline Hluhluwe River & KwaZulu-Natal & $1949,1951,1957,1983,1987$ & 2003 \\
\hline Mkuzi River & KwaZulu-Natal & $1969,1973,1977,1984,1988$ & \\
\hline Sabie River & Mpumalanga & $1970,1976,1980$ & 2001,2003 \\
\hline Olifants River & Limpopo & 1973 & $2010,2014,2015$ \\
\hline Nseleni River & KwaZulu-Natal & 1993, 1994 & 2000,2004 \\
\hline
\end{tabular}

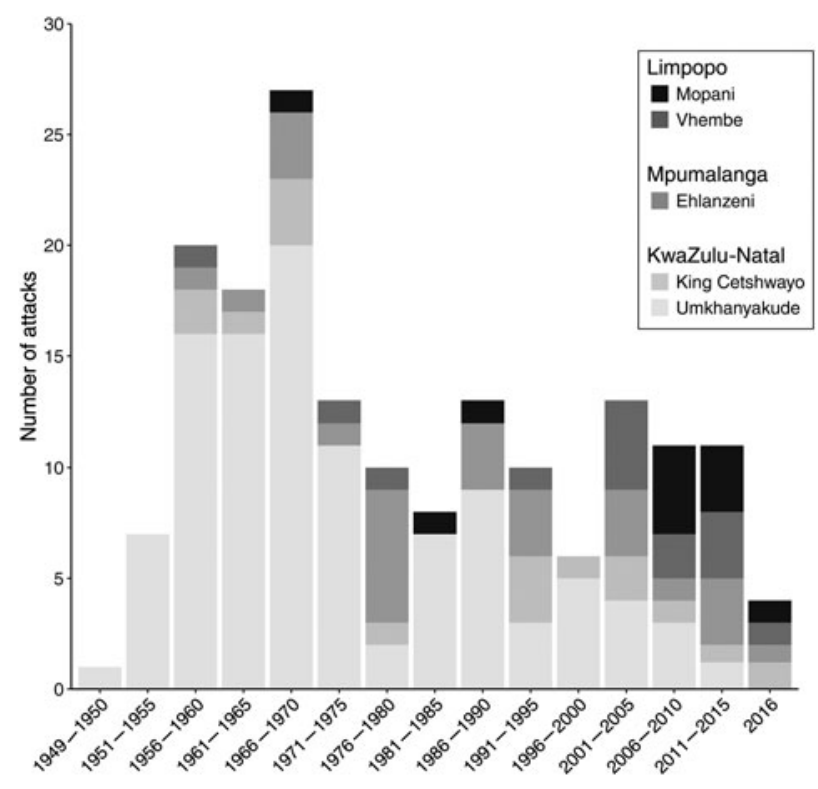

FIG. 2 Attacks recorded by 5-year period for the five municipal districts in South Africa with the highest number of attacks.

following seasonal fluctuations in mean monthly rainfall and mean monthly minimum temperature.

Victim demographics One hundred and ninety records include the activity the victim was engaged in when the attack occurred. Of these, most victims (31\%) were attacked while swimming or bathing $(n=59)$, followed by fishing ( $n=41,22 \%)$, doing domestic chores at the water's edge
( $\mathrm{n}=35,18 \%)$, crossing the water $(\mathrm{n}=30,16 \%)$, or other $(\mathrm{n}=25,13 \%)$. There was a significant relationship between gender and activity when attacked $\left(\chi^{2}=59.363, \mathrm{df}=4, \mathrm{n}=190\right.$, $\mathrm{P}<0.001)$. The data indicate a relationship between age (adult $\geq 16>$ child) and activity but this was not significant $\left(\chi^{2}=8.625, \mathrm{df}=4, \mathrm{n}=124, \mathrm{P}=0.071\right)$. Table 3 summarizes the number and per cent of attacks for each activity by age and gender. Of the reports including exact age information $(n=139), 68$ attacks (49\%) were on adults ( $\geq 16$ years), and 71 attacks $(51 \%)$ were on children $(<16$ years). A greater proportion of the attacks on children were fatal (54\%), compared with adults (35\%), and this difference is significant $\left(\chi^{2}=3.962, \mathrm{df}=1, \mathrm{n}=139, \mathrm{P}=0.047\right)$. Fig. 4 shows the distribution of victim ages, subset by fatal and non-fatal attacks.

\section{Discussion}

The analysis and interpretation of long-term data on crocodile attacks provide valuable information on the seasonality of attacks, locations of attacks and demographics of attack victims. Outcomes from this research could help focus mitigation efforts, provided that local contexts are taken into account, as outlined below.

\section{Seasonality of attacks}

Three possible explanations for the seasonality of crocodile attacks have been offered: increased dispersal and encounter rates resulting from high rainfall and water levels (wet 
(a)

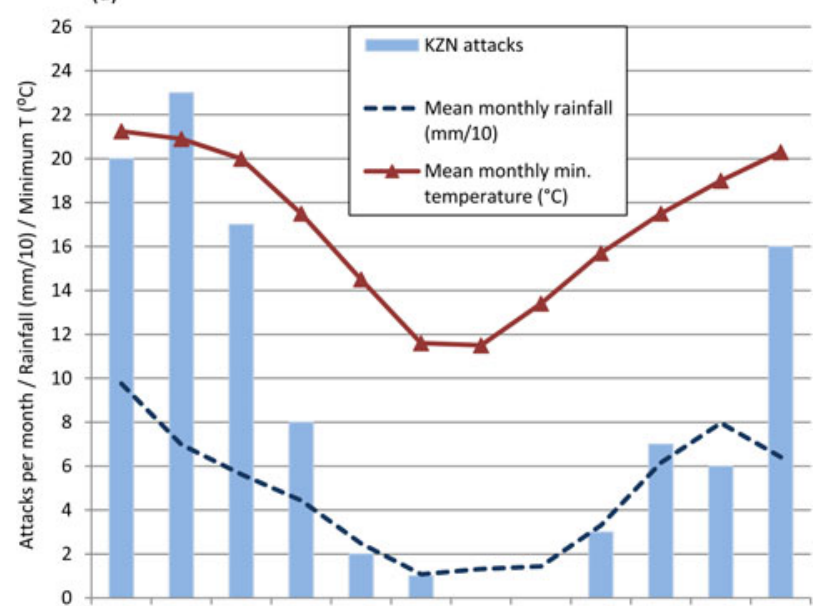

(b)

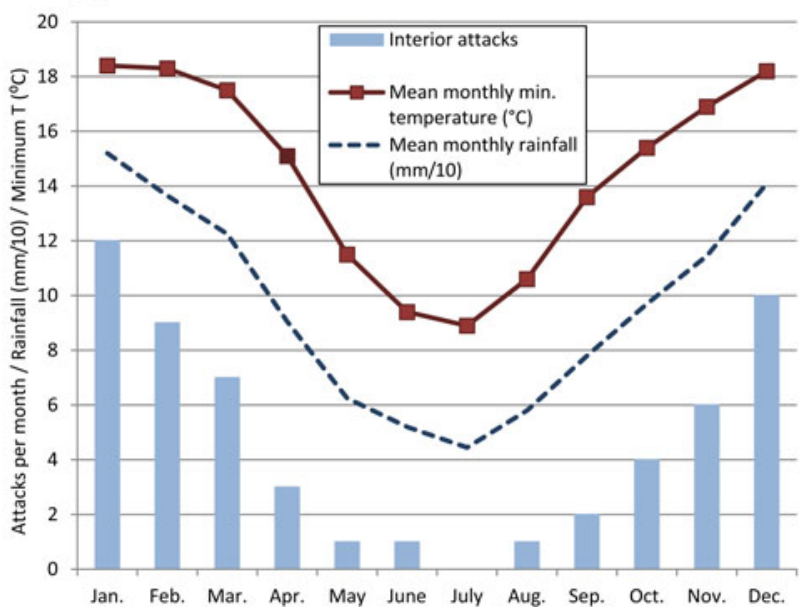

FIG. 3 Seasonality of crocodile attacks in (a) KwaZulu-Natal Province (KZN) and in (b) the interior provinces of South Africa, tracking seasonal fluctuations in mean monthly rainfall and mean monthly minimum temperature.

season), temperature (crocodiles are ectothermic and thus more active when it is warmer), and increased aggression during the breeding season (Pooley et al., 1992; Pooley, 2015a). Crocodile attack incidence tracks high mean water levels (where data exist) and high monthly mean rainfall (particularly in the interior of South Africa). However, preliminary studies indicate there is no significant relationship between individual attacks in the study region and high rainfall and water-level conditions recorded for dates of attacks only (Potter, 2014; Powell et al., 2019). In neighbouring Mozambique the short-term data (1997-2003) of Le Bel et al. (2011) indicate that most attacks occur in the dry season.

Monthly mean daily temperature is the strongest environmental predictor, with most attacks occurring at temperatures of $\geq 16^{\circ} \mathrm{C}$ (Potter, 2014; Powell et al., 2019; see Lance, 2003, on American alligators). This effect of temperature could be explained by crocodiles' decreased physiological maintenance costs under cooler conditions and, conversely, increased activity levels and food requirements under warmer conditions, as suggested for saltwater crocodiles Crocodylus porosus in Australia (Manolis \& Webb, 2013, p. 100).

The seasonality of crocodile attacks cannot be explained based on biophysical variables and crocodile behaviour alone because of the overlap between human and crocodile activity (e.g. the seasonality of aquatic activity of both crocodiles and people). Nearly half of attacks in the study region occurred on weekends and holidays, suggesting human activity patterns are influential. Although the climate varies slightly between the interior and the coastal regions where crocodiles occur, the peak attack season is the same: December-March (Fig. 3). More data on local behaviour patterns of crocodiles and people in hotspots for crocodile attacks would contribute to more effective mitigation measures. For instance, it is known that crocodiles congregate in lakes in Ndumo Game Reserve and on the eastern shores of Lake St Lucia in winter. Larger individuals disperse outside the protected areas or around the lake system in the summer. Thus in recreational areas around the Lake St Lucia system, notably the estuary, there are seasonal overlaps between the distributions of larger crocodiles and people (Pooley, 1982; Combrink, 2014).

\section{Spatial distribution of attacks}

Our data indicate that historically most attacks occurred in waterways linked with major crocodile populations, namely the St Lucia Lake system, Ndumo Game Reserve and Kruger National Park. This situation was exacerbated in South Africa by the Apartheid Homeland or Bantustan system under which Africans were relocated to remote rural regions with little infrastructure (Beinart, 2001). Wildlife conservation areas persisted where land was undesirable for farming and settlement (McCracken, 2008). Most crocodile attacks occurred where so-called native reserves bordered or were crossed by rivers linked with protected areas. In KwaZulu-Natal Province this includes former native reserves on the Hluhluwe, Nyalazi and Umfolozi rivers. In Mpumalanga, attack hotspots persisted where the former homeland of Gazankulu was located on the western border of Kruger National Park. In Limpopo Province, attacks persisted where the former homeland of Venda straddled rivers flowing into the Park.

Crocodile attack incidence does not track fluctuations in crocodile numbers (decline followed by a small recovery during 1957-1972, the period of peak attack incidence, and rapid recovery and stabilization during the period of reduced attacks, in the late 1980s-1990s). Shifts in the distributions of crocodiles as a result of environmental events (e.g. droughts, floods) and anthropogenic interventions (dam 
TABLE 3 Activities in which victims of crocodile attacks were engaged at the time of attack, by age category and gender, for incidents for which all details are known $(n=187)$.

\begin{tabular}{|c|c|c|c|c|c|}
\hline Activity & Women ( $\geq 16$ years $)$ & Men $(\geq 16$ years $)$ & Girls ( $0-15$ years $)$ & Boys (0-15 years) & Total \\
\hline $\begin{array}{l}\text { Crossing } \\
\text { waterways }\end{array}$ & $\begin{array}{l}11 \text { ( } 24 \% \text { of women; } 38 \% \\
\text { of crossing victims) }\end{array}$ & $\begin{array}{l}10 \text { ( } 15 \% \text { of men; } 34 \% \\
\text { of crossing victims) }\end{array}$ & $\begin{array}{l}6 \text { (23\% of girls; } 21 \% \\
\text { of crossing victims) }\end{array}$ & $\begin{array}{l}2 \text { ( } 4 \% \text { of boys; } 7 \% \\
\text { of crossing victims) }\end{array}$ & 29 \\
\hline $\begin{array}{l}\text { Domestic chores } \\
\text { at water's edge }\end{array}$ & $\begin{array}{l}19 \text { ( } 42 \% \text { of women; } 56 \% \\
\text { of domestic chores } \\
\text { victims) }\end{array}$ & $\begin{array}{l}1 \text { ( } 2 \% \text { of men; } 3 \% \\
\text { of domestic chores } \\
\text { victims) }\end{array}$ & $\begin{array}{l}11 \text { ( } 42 \% \text { of girls; } 32 \% \\
\text { of domestic chores } \\
\text { victims) }\end{array}$ & $\begin{array}{l}3 \text { ( } 6 \% \text { of boys; } 9 \% \\
\text { of domestic chores } \\
\text { victims) }\end{array}$ & 34 \\
\hline Fishing & $\begin{array}{l}6 \text { ( } 13 \% \text { of women; } 15 \% \\
\text { of fishing victims) }\end{array}$ & $\begin{array}{l}25 \text { ( } 38 \% \text { of men; } 61 \% \\
\text { of fishing victims) }\end{array}$ & $\begin{array}{l}2 \text { ( } 8 \% \text { of girls; } 5 \% \\
\text { of fishing victims) }\end{array}$ & $\begin{array}{l}8 \text { ( } 16 \% \text { of boys; } 20 \% \\
\text { of fishing victims) }\end{array}$ & 41 \\
\hline $\begin{array}{l}\text { Swimming or } \\
\text { bathing }\end{array}$ & $\begin{array}{l}2 \text { ( } 4 \% \text { of women; } 4 \% \\
\text { of swimming victims) }\end{array}$ & $\begin{array}{l}18 \text { ( } 27 \% \text { of men; } 33 \% \\
\text { of swimming victims) }\end{array}$ & $\begin{array}{l}5 \text { ( } 19 \% \text { of girls; } 9 \% \\
\text { of swimming victims) }\end{array}$ & $\begin{array}{l}29 \text { (58\% of boys; } 54 \% \\
\text { of swimming victims) }\end{array}$ & 54 \\
\hline Other & $\begin{array}{l}7 \text { ( } 16 \% \text { of women; } 24 \% \\
\text { of other victims) }\end{array}$ & $\begin{array}{l}12 \text { ( } 18 \% \text { of men; } 41 \% \\
\text { of other victims) }\end{array}$ & $\begin{array}{l}2 \text { ( } 8 \% \text { of girls; } 7 \% \\
\text { of other victims) }\end{array}$ & $\begin{array}{l}8 \text { ( } 16 \% \text { of boys; } 28 \% \\
\text { of other victims) }\end{array}$ & 29 \\
\hline Total & 45 & 66 & 26 & 50 & 187 \\
\hline
\end{tabular}

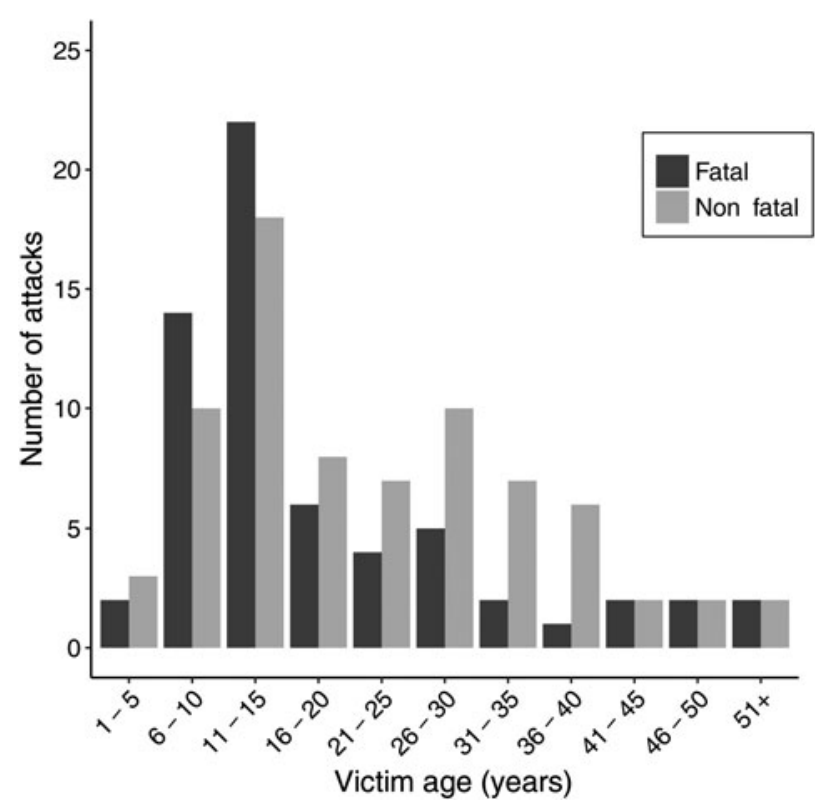

FIG. 4 Distribution of victims by 5-year age groups, subset by fatal and non-fatal attacks. Note the high proportion of, and higher fatalities in, children aged 6-15 years.

building, pollution, habitat transformation, direct persecution), and rapid urbanization of South Africa's human population since the 1980 s seem to be of greater consequence (Pooley, 2013).

An upwards trend in attacks in the interior since 2000 may be the result of encounters with crocodiles in unexpected locations, notably dams, where they have moved in response to the drying up of perennial rivers, disturbances along the riverbanks, or pollution in rivers (Botha et al., 2011). Some have been displaced through habitat loss caused by the widespread raising of the walls of larger dams in South Africa, notably Flag Boshielo Dam, and the $150 \mathrm{~km}^{2}$ Massingir Dam in Mozambique, both on the Olifants River (Harvey \& Marais, 2014, p. 88).
Commercial and subsistence fishing on a number of dams inhabited by crocodiles are an ongoing safety concern (Tapela et al., 2015). The key dams include Flag Boshielo Dam and the $0.75 \mathrm{~km}^{2}$ Makuleke Dam, and possibly Middle Letaba Dam (18.79 $\mathrm{km}^{2}$, in Limpopo Province) and Driekoppies Dam (18.7 km², in Mpumalanga).

Some of South Africa's historically most problematic rivers for crocodile attacks (including the Usutu, the Pongola and its pans, and the Mkuzi River) have had few attacks since 2000, possibly offering proxy data that few crocodiles survive outside protected areas in these river systems (Table 2). Since 2000 there have continued to be attacks in the rivers listed in Table 4 and in the St Lucia system. Attacks since 2000 are listed separately because they are of more relevance for managers, as they reflect more recent trends in attack incidence. Dams in or near waterways listed in Table 4, and in addition the Limpopo River (where crocodile populations may be recovering), should be regarded as higher-risk areas, as they have more recent records of attacks. Of the 17 attacks recorded in eSwatini during 2000-2016, $65 \%$ occurred in the Usutu (or Lusutfu) River, and $29 \%$ in the Mbuluzi River.

\section{Victim demographics}

The finding that it is mostly males $(65 \%)$ that have been attacked in this region contradicts the assumption that in Africa women and girls are disproportionately at risk because of their domestic tasks at the water's edge (e.g. Lamarque et al., 2009, p. 19). The numerous attacks on females, most performing domestic chores, along the Pongola floodplain system in the 1960 s and 1970s are atypical. Census data reveal a higher proportion of women than men resident in this region in this period, with men away working as migrant labourers (Smedley \& Ribeiro-Tôrres, 1979). Our data show that domestic chores have been a less important factor in the wider region since c. 2000 , 
TABLE 4 Key areas and water bodies in South Africa where crocodile attacks took place during 200o-2016. For each province only the district municipality with most attacks is included, and only rivers or river or lake systems (key water bodies) with numerous attacks are shown.

\begin{tabular}{llll}
\hline District municipality (by province) & Key water body & $\begin{array}{l}\text { No. of attacks in } \\
\text { natural waterways }\end{array}$ & $\begin{array}{l}\text { No. of attacks in } \\
\text { dams \& canals }\end{array}$ \\
\hline $\begin{array}{l}\text { KwaZulu-Natal } \\
\text { Umkhanyakude }\end{array}$ & St Lucia Lake System & 8 & 0 \\
$\begin{array}{l}\text { King Cetshwayo } \\
\text { Limpopo }\end{array}$ & Mhlatuze/Nseleni ${ }^{1}$ rivers system & 7 & 1 \\
Vhembe & Mutshindudi River & 4 & 0 \\
Mopani & Luvuvhu River & 3 & 0 \\
Mpumalanga & Olifants River & 3 & 0 \\
Ehlanzeni & Sabie River & 2 & 2 \\
Total & & 27 & 3 \\
\hline
\end{tabular}

${ }^{1}$ The Nseleni River is linked to the Goedertrouw Dam.

reflecting both the crocodile's contracting range and improved water provision in some rural areas.

A key finding is that $51 \%$ of victims were aged $0-15$ years. That $62 \%$ of victims were aged $0-20$ and the largest adult category was $21-30$ (19\%) may simply reflect the demography of the country (median age 26). Nevertheless, the high proportion of children, especially aged 11-15 years, $72.5 \%$ of whom were boys, suggests this should be a focus for concern and education.

The overall fatality rate from attacks was 49\% (19492017), comparable to the findings of Thomas (2006) for the Okavango Swamps (55\%) and Maheritafika et al. (2016) for Madagascar (56\%), but notably lower than the $63 \%$ estimated by Fergusson (2004) for Africa in general. However, $57 \%$ of attacks on children (o-15 years) were fatal $(n=65)$ and $54 \%$ of victims aged o-20 years were killed $(\mathrm{n}=79)$, in comparison with $40 \%$ of attacks on those aged $\geq 21$ years $(n=45)$. Fatality rates were influenced by whether the victim was accompanied or alone, and the size (length) of crocodile involved, as well as the size of the victim. Smaller victims (children) are more vulnerable to fatal attacks, as found in an analysis of factors affecting the survival of victims of attacks by saltwater crocodiles (Fukuda et al., 2015). We found that, of those adults who escaped death, $57 \%$ (29) escaped without help and $43 \%$ (22) were rescued, whereas only $35 \%$ (11) of children escaped unaided and $65 \%(20)$ were rescued.

Only 15 crocodiles involved in attacks were measured accurately, and therefore size data could not be used as an accurate variable. Furthermore, most crocodile counts have been made from fixed-wing aircraft (X. Combrink, pers. obs.), so there are no general data on the size of crocodiles to facilitate comparison of the number of fatal attacks with the proportion of large crocodiles in wild populations. Comparing the length of crocodiles with fatality/nonfatality outcomes is complicated by age and size of victim,

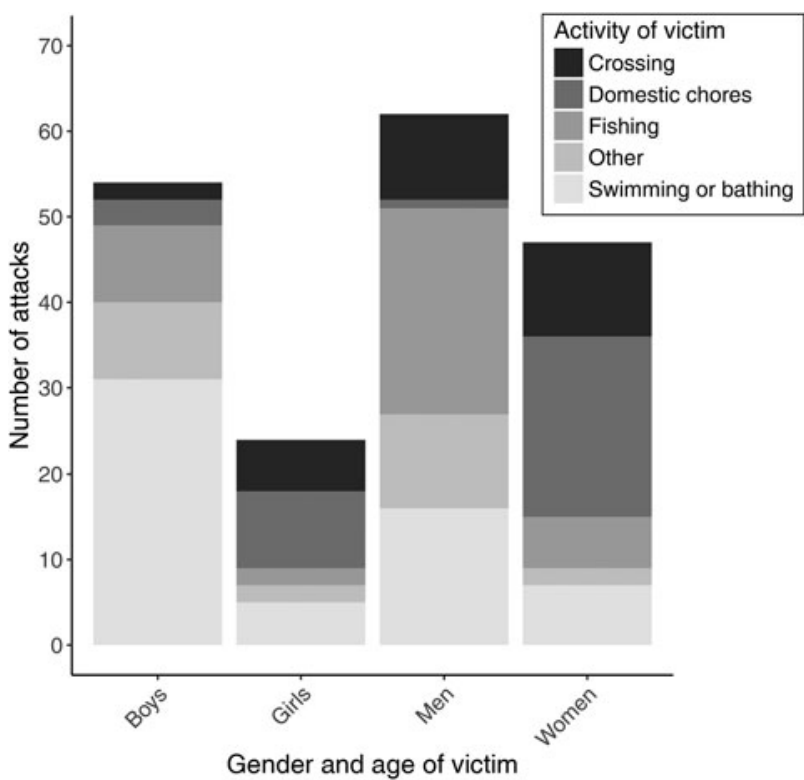

FIG. 5 Profiles of activities of victim by gender and age group (adult or child).

and whether there were rescuers present. Better data would be required to assess the relationship between size and deliberate attacks on people by crocodiles in this region, although data from alligators and saltwater crocodiles suggest that individuals measuring $>1.8 \mathrm{~m}$ can inflict serious injuries, and individuals measuring $\geq 2.4 \mathrm{~m}$ carry out fatal attacks (Caldicott et al., 2005; Fukuda et al., 2015).

Overall, most victims were swimming, bathing or fishing, but disaggregating data on activity of victim when attacked by age and gender reveals distinct profiles (Fig. 5). Thomas (2006) and Wallace et al. (2011) found similar results in the Okavango Swamps (Botswana) and lower Zambezi (Zambia), respectively. Our data show that until the $1980 \mathrm{os}$ 
most victims were performing domestic chores or crossing water when attacked, but since then these activities have been superseded by swimming and fishing.

\section{Management recommendations}

For high risk areas there are a number of mostly low-cost actions that can be taken. Local authorities could facilitate safe water crossings, and safe access to water for swimming (particularly near rural schools) or domestic needs, including alternatives such as water tanks, piped water and protective enclosures.

Provincial conservation authorities and district municipalities could create, equip and train teams to capture and remove problem crocodiles. Where such teams already exist, it would be helpful to make them known to the public. If departmental resources are limited, a system of licensing private individuals (as in the USA) could be trialled (Dutton et al., 2014; King \& Elsey, 2014). Some commercial crocodile farmers already provide this service on an ad hoc basis. Removing crocodiles requires the creation of clear protocols for disposing of captured crocodiles.

Educating children should be a priority, particularly in identified high-risk areas. Outreach activities could be supported with existing materials (Pooley, 2015b; Pooley, 2017) that provide information on crocodile biology and behaviour, their ecological and conservation importance, as well as advice on avoiding and responding to attacks.

Provincial conservation authorities should appoint knowledgeable spokespersons to brief the public in the event of a crocodile attack (or alleged attack). The accuracy of reporting would be improved by keeping detailed records of attacks, and building better communication between police, coroners and conservation authorities to ensure accurate information on causes of death are reported. In South Africa, where crocodiles are farmed but not ranched (i.e. captive bred but not sourced from the wild) and there is no link between farming and the country's wild populations of crocodiles, and in a region where taboos against the eating of crocodiles have recently been overturned (Viljoen, 2014; Zulu, 2015), tolerance for wild crocodiles should not be taken for granted.

Acknowledgements SP thanks Vince Egan, Tal Fineberg, Mick Reilly and Freek Venter for information on management policies. We are grateful for constructive comments from Martin Fisher and two anonymous referees. Fig. 1 was created by Martin Fisher. SP is funded by the Lambert Bequest at Birkbeck University of London.

Author contributions Collection and collation of attack data and historical information, writing: SP; contribution of insights on crocodile populations and management: $\mathrm{XC}, \mathrm{HB}$; statistical analyses and figures: GP.

\section{Conflicts of interest None.}

Ethical standards This research abided by the Oryx guidelines on ethical standards.

\section{References}

Anthony, B.P., Scott, P. \& Antypas, A. (2010) Sitting on the fence? Policies and practices in managing human-wildlife conflict in Limpopo Province, South Africa. Conservation \& Society, 8, 225-240.

Ashton, P.J. (2010) The demise of the Nile crocodile (Crocodylus niloticus) as a keystone species for aquatic ecosystem conservation in South Africa: the case of the Olifants River. Aquatic Conservation, 20, 489-493.

Aust, P., Boyle, B., Fergusson, R. \& Coulson, T. (2009) The impact of Nile crocodiles on rural livelihoods in northeastern Namibia. South African Journal of Wildlife Research, 39, 57-69.

Beinart, W.J. (2001) Twentieth-Century South Africa. Oxford University Press, Oxford, UK.

Big Game Parks (2017) Conservation. Https://biggameparks.org/ conservation [accessed 6 June 2018].

Вотна, P.J. (2005) The ecology and population dynamics of the Nile crocodile Crocodylus niloticus in the Flag Boshielo Dam,

Mpumalanga Province, South Africa. MSc thesis. University of Pretoria, South Africa.

Botha, H., van Hoven, W. \& Guillette, Jr, L.J. (2011) The decline of the Nile crocodile population in Loskop Dam, Olifants River, South Africa. Water SA, 37, 103-108.

Brien, M.L., Gienger, C.M., Browne, C.A., Read, M.A., Joyce, M.J. \& Sullivan, S. (2017) Patterns of human-crocodile conflict in Queensland: a review of historical estuarine crocodile (Crocodylus porosus) management. Wildlife Research, 44, 281-290.

Caldicott, D.G.E., Croser, D., Manolis, C., Webb, G. \& Britton, A. (2005) Crocodile attack in Australia: an analysis of its incidence and review of the pathology and management of crocodilian attacks in general. Wilderness \& Environmental Medicine, 16, 143-159.

Calverley, P.M. \& Downs, C.T. (2014a) Population status of Nile crocodiles in Ndumo Game Reserve, KwaZulu-Natal, South Africa (1971-2012). Herpetologica, 70, 417-425.

Calverley, P.M. \& Downs, C.T. (2014b) Habitat use by Nile crocodiles in Ndumo Game Reserve, South Africa: a naturally patchy environment. Herpetologica, 70, 426-438.

Champion, G. \& Downs, C.T. (2017) Status of the Nile crocodile population in Pongolapoort Dam after river impoundment. African Zoology, 52, 55-63.

Christopher, A.J. (2011) The Union of South Africa censuses 1911-1960: an incomplete record. Historia, 56, 1-18.

CiA (Central Intelligence Agency) (2017) The World Factbook. Https://www.cia.gov/library/publications/resources/the-worldfactbook/geos/wz.html [accessed 6 June 2018].

Combrink, X. (2014) Spatial and reproductive ecology and population status of the Nile crocodile (Crocodylus niloticus) in the Lake St Lucia Estuarine System, South Africa. PhD thesis. University of KwaZulu-Natal, Pietermaritzburg, South Africa.

Combrink, X., Warner, J.K. \& Downs, C.T. (2013) Crocodiles. In Ecology and Conservation of Estuarine Ecosystems: Lake St Lucia as a Global Model. (eds R. Perissinotto, D.D. Stretch \& R.H. Taylor), pp. 332-353. Cambridge University Press, Cambridge, UK.

CrocBITE (2018) Worldwide Crocodilian Attack Database. Http://www.crocodile-attack.info [accessed 13 September 2018].

DAs, C.S. \& JANA, R. (2018) Human-crocodile conflict in the Indian Sundarban: an analysis of spatio-temporal incidences in relation to people's livelihood. Oryx, 52, 661-668.

Dunham, K.M., Ghiurghi, A., Cumbi, R. \& Urbano, F. (2010) Human-wildlife conflict in Mozambique: a national perspective, with emphasis on wildlife attacks on humans. Oryx, 44, 185-193.

Dutton, H.J., Waller, J.E., Carbonneau, D.A., Hord, L.J., Stiegler, S.G., Woodward, A.R. et al. (2014) Florida's Alligator 
Management Program: an update 2002-2014. In Proceedings of the 23rd Working Group Meeting of the IUCN Crocodile Specialist Group, pp. 60-71. IUCN, Gland, Switzerland.

Fergusson, R.A. (2004) Preliminary analysis of data in the African human-crocodile conflict database. Crocodile Specialist Group Newsletter, 23, 21.

Fergusson, R.A. (2010) Nile crocodile Crocodylus niloticus. In Crocodiles: Status Survey and Conservation Action Plan, 3rd edition. (eds S.C. Manolis \& C. Stevenson), pp. 84-89. Crocodile Specialist Group, Darwin, Australia.

Ferreira, S.M. \& PienaAr, D. (2011) Degradation of the crocodile population in the Olifants River Gorge of Kruger National Park, South Africa. Aquatic Conservation, 21, 155-164.

Fukuda, Y., Manolis, S.C., SaAlfeld, K. \& Zuur, A. (2015) Dead or alive? Factors affecting the survival of victims during attacks by saltwater crocodiles (Crocodylus porosus) in Australia. PLOS ONE, 10, e0126778.

Giraut, F. \& Vacchiani-Marcuzoo, C. (2009) Territories and Urbanisation in South Africa. Institut de Recherche pour le Developpement, Marseille, France.

Harvey, J. \& Marais, J. (2014) Family Crocodylidae. In Atlas and Red List of the Reptiles and Amphibians of South Africa, Lesotho and Swaziland. (eds M.F. Bates, W.R. Branch, A.M. Bauer, M. Burger, J. Marais, G.J. Alexander et al.), pp. 86-88. SANBI, Pretoria, South Africa.

Jacobsen, N.H.G. (1984) The distribution and status of crocodile populations in the Transvaal outside the Kruger National Park. Biological Conservation, 29, 191-200.

KING, R. \& ELSEY, R. (2014) Louisiana's nuisance alligator program. In Proceedings of the 23rd Working Group Meeting of the IUCN Crocodile Specialist Group, pp. 163-181. IUCN, Gland, Switzerland.

Kpéra, G.N., Aarts, N., Tossou, R.C., Mensah, G.A., Saìdou, A., Kossou, D.K. et al. (2014) 'A pond with crocodiles never dries up' a frame analysis of human-crocodile relationships in agro-pastoral dams in Northern Benin. International Journal of Agricultural Sustainability, 12, 316-333.

Lamarque, F., Anderson, J., Fergusson, R. , Lagrange, M., Osei-Owusu, Y. \& B AKker, L. (2009) Human-Wildlife Conflict in Africa: Causes, Consequences and Management Strategies. Food and Agriculture Organization, Rome, Italy.

LANCE, V.A. (2003) Alligator physiology and life history: the importance of temperature. Experimental Gerontology, 38, 801-805.

Le Bel, S., Murwira, A., Mukamuri, B., Czudek, R., Taylor, R. \& LA Grange, M. (2011) Human wildlife conflicts in southern Africa: riding the whirl wind in Mozambique and in Zimbabwe. In The Importance of Biological Interactions in the Study of Biodiversity (ed. J. Lapez-Pujol), pp. 283-322. InTech, Rijeka, Croatia.

Maheritafika, H.M.R., Robsomanitrandrasana, E., Rabesihanaka, S., Rafenomanana, F., Ravaoarimalala, A., Andrianjaratina, L. et al. (2016) Preliminary assessment of human-crocodile conflict in Madagascar. Newsletter of the Crocodile Specialist Group, 35, 19-21.

Manolis, S.C. \& Weвв, G.J. (2013) Assessment of saltwater crocodile (Crocodylus porosus) attacks in Australia (1971-2013), implications for management. In Proceedings of the 22nd Working Meeting of the IUCN-SSC Crocodile Specialist Group, 21-23 May 2013, pp. 97-104. IUCN, Gland, Switzerland.

McCracken, D. (2008) Saving the Zululand Wilderness: an Early Struggle for Nature Conservation. Jacana, Johannesburg, South Africa.

NOAA (National Oceanic and Atmospheric Administration) (2017) NOAA National Climate Data Center. Http://www.ncdc.noaa.gov/ cdo-web/search [accessed 13 September 2018].

NOAa Central Library (2013) South Africa Climatological Data. Https://library.noaa.gov/Collections/Digital-Docs/Foreign-
Climate-Data/South-Africa-Climate-DataH [accessed 13 September 2018].

Pooley, A.C. (1980) Crocodile research in Maputaland. In Studies on the Ecology of Maputaland (eds M.N. Bruton \& K.H. Cooper), pp. 293-299. Rhodes University Press, Grahamstown, South Africa.

Pooley, A.C. (1982) The ecology of the Nile crocodile, Crocodylus niloticus, in Zululand, South Africa. MSc thesis. University of Natal, Pietermaritzburg, South Africa.

Pooley, S. (2013) No tears for the crocodile: investigating calls for the extermination of the Nile crocodile in Zululand, South Africa, to c. 1958. In Wild Things: Nature and the Social Imagination (eds W. Beinart, K. Middleton \& S. Pooley), pp. 142-162. White Horse Press, Cambridge, UK.

Pooley, S. (2015a) Using predator attack data to save lives, human and crocodilian. Oryx, 49, 581-583.

Pooley, S. (2015b) Don't Get Eaten by a Crocodile in South Africa or Swaziland. Simon Pooley, London, UK.

Pooley, S. (2017) Don't get eaten by a croc. Https://www.researchgate. net/publication/320383558_Don\%27t_Get_Eaten_by_a_Croc [accessed 13 September 2018].

Pooley, S. (2018) Croc Digest: a Bibliography of Human-Crocodile Conflict Research and Reports, 2nd ed. Simon Pooley, London, UK.

Pooley, A.C., Hines, T. \& Shield, J. (1992) Attacks on humans. In Crocodiles and Alligators. 2nd edition. (ed. C.A. Ross), pp. 172-187. Blitz Editions, London, UK.

Potter, J. (2014) Analysis of human-crocodile conflict with envelope modelling. MSc thesis. Imperial College London, London, UK.

Powell, G., Versluys, T.M.M., Williams, J., Tiedt, S. \& Pooley, S. (2019) Using environmental niche modelling to investigate the importance of ambient temperature in human-crocodilian attack occurrence for two species of crocodilian. Oryx, in press.

Shaney, K.J., Hamidy, A., Walsh, M., Arida, E., Arimbi, A. \& SMITH, E.N. (2017) Impacts of anthropogenic pressures on the contemporary biogeography of threatened crocodilians in Indonesia. Oryx, published online 10 November 2017.

Smedley, L.N., \& Ribeiro-Tôres, J.L. (1979) Man and the Pongolo Floodplain: a Preliminary Study. Report No.S-62. South African Human Sciences Research Council, Pretoria, South Africa.

Tapela, B.N., Britz, P.J. \& Rouhani, Q.A. (2015) Scoping Study on the Development and Sustainable Utilisation of Inland Fisheries in South Africa. Vol. 2 Case Studies, Report No. TT 615/2/14. Water Research Commission, Gezina, South Africa.

Thomas, G.D. (2006) Human-crocodile conflict (Nile crocodile: Crocodylus niloticus) in the Okavango Delta, Botswana. MSc thesis. University of Stellenbosch, South Africa.

Turok, I. (2012) Urbanisation and Development in South Africa. Urbanisation and Emerging Population Issues. Working paper 8. IIED, London, UK.

UNDP (United Nations Development Programme) (2018) Human Development Reports. Http://hdr.undp.org/en/countries/ profiles [accessed 3 October 2018].

Viljoen, A. (2014) Soweto next for Dan's croc braai. The Witness, 13 March 2014.

Vyas, R. \& SteVenson, C. (2017) Review and analysis of human and Mugger crocodile conflict in Gujarat, India from 1960 to 2013. Journal of Threatened Taxa, 9, 11,016-11,024.

Wallace, K.M., Leslie, A.J. \& Coulson, T. (2011) Living with predators: a focus on the issues of human-crocodile conflict within the lower Zambezi valley. Wildlife Research, 38, 747-755.

ZAKAY O, F. (2014) Human-crocodile conflicts in areas adjacent to Lake Rukwa and Momba River, Momba District, Tanzania. MSc thesis. Sokoine University of Agriculture, Morogoro, Tanzania.

Zulu, J. (2015) Tail most eaten. Times of Swaziland, 5 February 2015. 